DOI:10.2478/cpp-2018-0011

\title{
Neurotic symptoms in clinical practice: Mieczysław Kaczyński's approach
}

\author{
Objawy nerwicowe w praktyce klinicznej wg prof. Mieczysława Kaczyńskiego
}

Aneta Perzyńska - Starkiewicz A,B,E,F

II Department of Psychiatry and Psychiatry Rehabilitation, Medical University of Lublin

\begin{abstract}
The aim of this study is to acquaint the readers with some pieces of practical guidance on the therapy of neurotic disorders offered by Professor Mieczysław Kaczyński to his colleagues and students at the Lublin Clinic of Psychiatry. Patients who report so-called neurotic complaints are a group that requires a very thorough clinical analysis. Professor Kaczyński emphasized that it was necessary to make a distinction among patients with a neurotic reaction, a pseudoneurotic syndrome, and 'neurosis proper' or psychoneurosis. The first group includes patients who report a psychological trauma as a trigger of their complaints. Therapeutic intervention brings good outcomes leading to resolution of the condition. A group of patients that is very important from the point of view of diagnosis are those in whom neurotic complaints are masking an onset of a somatic or mental illness or an existing illness which is running a mild course. In such cases, a cursory examination leading to a mistaken diagnosis of neurosis can have devastating effects. A misdiagnosis is easy to make, for example, in patients with increased intracranial pressure ("the neurasthenic stage of a brain tumour") or an onset of a mental illness (the pseudoneurotic syndrome of early schizophrenia). Therefore, often, before the final diagnosis is arrived at, multiple follow-up examinations are needed to monitor the structure and dynamics of the disease. Only when the first two diagnostic options have been excluded, can the physician classify the disorder as a neurosis (psychoneurosis). In such cases, it is necessary to find the etiological agent, which, more often than not, is a situation of conflict or frustration that the patient is unconscious of. A failure to analyze a case in this way may result in the patient's resignation response, potentially leading to suicide. It appears that Professor Kaczyński's remarks on the clinical picture of neurotic disorders largely round out the information provided in ICD-10 under F.40-F.48.
\end{abstract}

Keywords: neurotic symptoms, clinical practice, suicidal resignation response

\section{Streszczenie}

Celem pracy jest przedstawienie praktycznych wskazówek, dotyczących terapii zaburzeń nerwicowych, przekazywanych przez prof. Mieczysława Kaczyńskiego, w lubelskiej Klinice Psychiatrii. Pacjenci, zgłaszający tzw. skargi nerwicowe, stanowią grupę wymagającą bardzo wnikliwej analizy klinicznej. Prof. M. Kaczyński podkreślał, że konieczne jest różnicowanie między: - reakcją nerwicową, - zespołem rzekomonerwicowym i - tzw. „nerwicą prawdziwą” lub psychonerwicą. Do pierwszej grupy, należą pacjenci, którzy wskazują na uraz psychiczny wyzwalający zgłaszane skargi. Pomoc terapeutyczna, przynosi dobre rezultaty i schorzenie ustępuje. Bardzo ważną diagnostycznie grupą są pacjenci, u których dolegliwości nerwicowe maskują, rozpoczynające się lub istniejące, lecz o łagodnym przebiegu schorzenie somatyczne lub chorobę psychiczną. W takich przypadkach, powierzchowne badanie zakończone błędną diagnozą nerwicy, może spowodować dramatyczne skutki. Tak może być w przypadku np. wzrostu ciśnienia śródczaszkowego ( „stadium neurasteniczne guza mózgu”) lub rozpoczynającej się choroby psychicznej ( zespół rzekomo nerwicowy rozpoczynającej się schizofrenii ). Dlatego, przed ostateczną diagnozą, konieczne są nieraz wielokrotne badania kontrolne, monitorujące strukturę i dynamikę schorzenia. Wykluczenie dwóch pierwszych możliwości diagnostycznych, upoważnia do zakwalifikowania schorzenia do grupy nerwic (psychonerwic). W takich przypadkach, konieczne jest ujawnieni czynnika etiologicznego, którym najczęściej jest nieuświadamiana sobie przez pacjenta, sytuacja konfliktowa lub frustracyjna. Brak takiej analizy, może skutkować rozwojem, zagrażającej śmiercią samobójczą, reakcji rezygnacyjnej. Wydaje się, że przytoczenie uwag 
prof. M. Kaczyńskiego, dotyczących obrazu klinicznego zaburzeń nerwicowych, może stanowić dopełnienie informacji, objętych kodami alfanumerycznymi F.40 - F.48 Klasyfikacji ICD-10.

Słowa kluczowe: objawy nerwicowe, praktyka kliniczna, reakcja rezygnacyjna samobójcza

A review of journals and textbooks devoted to psychiatric disorders published over the last decade shows that neuroses, first identified by Cullen in 1776 and considered to be diseases of the nineteenth and then the twentieth century, currently do not spark any major interest with clinicians. One example is the textbook by Kaplan et al. [1], in which information on neuroses is practically limited to one item listed in the keyword index: 'compensation neurosis'. The textbook was based on the DSM-IV classification.

Thorough knowledge about the clinical aspects of neuroses is provided by Aleksandrowicz in his 1988 monograph Nerwice, psychopatologia, psychoterapia (Neurology, Psychopathology, and Psychotherapy), published by PZWL. [2]. The author states that neuroses "in epidemiological terms, are a leading problem of modern medicine". Even though almost 30 years have passed since the book was first published, the author's claim that "most doctors know little about these conditions and feel helpless when faced with them (which is why patients seek help from various different specialists and 'healers')" still holds true.

The 'confusion' regarding the diagnosing of neurotic disorders is attested in diagnoses found in archival medical records, and not only those made by general practitioners but also by psychiatrists. Looking through medical documentation, one can come across various descriptions of neuroses, such as 'anxiety-related', 'vegetative', 'situational', 'hypochondriacal', 'cardiac', 'compensation', 'traumatic', etc. The last of these terms was long ago blacklisted by Bilikiewicz as 'misleading', because this type of condition may be produced not so much by a psychogenic factor as an organic brain lesion [3].

More than 40 years ago, Falicki postulated that the so-called 'first-time' patients reporting neurotic complaints should be given, until an etiologic agent had been identified, a preliminary diagnosis of 'neurotic syndrome' [4]. An example of such a routine is found in a case report by Basquin: the patient had initially been recognized to suffer from neurosis, a diagnosis that was later changed to an equally erroneous diagnosis of schizophrenia, to be finally identified to have Wilson's disease [5].

Siwak-Kobayashi believes that "in general practice" neurotic disorders "are the most commonly encountered mental disorders" and that "they often give rise to numerous doubts and difficulties of a diagnostic and therapeutic nature." She points out that it is necessary to discriminate among conditions which are caused by different factors such as somatic problems, an addiction, or a residual presentation of an endogenous psychosis [6].

Ten years after the publication of Aleksandrowicz's book, a monograph by Kokoszka devoted to neurotic disorders [7] appeared in print (and was republished 6 years later). Following the ICD-10 Classification, which had been in use since 1998, the author stated that "the term neurosis is used occasionally and in a very general sense". Referring to the controversies that arose around the term at that time, he quoted the words of Norman Sartorius, the then Director of the WHO Division of Mental Health, who said that there had been no attempt to provide a definition of this term within the classification, however, the term 'neurotic' was still retained "as a concession to traditional usage". A recently published monograph on neurotic disorders in the practice of the primary care physician edited by Jarema [8] elaborates on the information outlined in ICD-10 under codes F.40-F.48 saying that "Although we do not diagnose neurosis, at least not in medical records, we accept the term neurotic disordersasdisorders as describing disorders with a more or less similar clinical picture, and possibly a common genesis." [8].

Professor Mieczysław Kaczyński, a student and then a collaborator of Professor Mazurkiewicz's, was the Head of the Lublin Clinic of Psychiatry in the years 1950-1971. Kaczyński's main scientific interests lay with the initial phase of schizophrenia and the characterological changes associated with this disease. His clinical analyses also focused on the emotional states of persons in the period of involution (he described so-called "involutional attitudes"), as well as psychological changes in the course of chronic neurotic disorders [9].

Kaczyński emphasized that all complaints reported by the patient which can be labelled with the umbrella term of 'neurosis' must be subjected to careful clinical analysis that will allow to classify them into one of the three diagnostic groups described below. The first group of complaints are the so-called 'neurotic reactions', i.e., short-lived mental dysfunctions related to a mental trauma reported by the patient. The features that figure prominently in the clinical picture of these reactions are characteristic of reactive disorders described by Jaspers - in this case without a psychotic symptomatology but with vegetative symptoms variously manifested depending on the patient's personality traits. Psychiatric and psychological assistance brings 
a good outcome. Symptoms of the reactions resolve without any sequelae. The second diagnostic group are so-called 'pseudoneurotic syndromes', whose symptoms resemble those of neurotic psychogenic disorders, but are caused either by somatic disorders, both developing (e.g. the 'neurasthenic stage' of a brain tumour) and chronic ones (e.g. presenting in the course of arterial hypertension or thyroid dysfunction), or an early-stage or a chronic (residual) mental illness. In such cases, which are the most difficult to diagnose, patients require multiple follow-up examinations carried out at short time intervals to evaluate the structure and dynamics of the disease.

A neurotic syndrome can be a prelude to an insidiously developing schizophrenia. Research conducted at the Lublin Clinic of Psychiatry has led to the identification of features that differentiate between psychogenically conditioned neuroses and the similar, but structurally and dynamically different, pseudoneurotic syndromes of early schizophrenia [10]. The differences in the clinical pictures had previously been pointed out by Kaczyński [11] and Masiak [12].

The third group of disorders with neurotic symptoms are 'neuroses proper', also referred to, by some authors who want to emphasize their psychogenic aetiology, as 'psychoneuroses'. A diagnosis of neurosis proper can only be made once 'neurotic reactions' and the 'pseudoneurotic syndrome' have been excluded. The diagnoses cited at the beginning of this paper, such as 'situational neurosis' or 'vegetative neurosis', are erroneous because each neurosis is 'situational' and 'vegetative'. The same holds true for socalled 'organ-specific neuroses' such as 'neurosis of the stomach' or 'cardiac neurosis'. The term neurosis refers to a patent's mental state, and the complaints about the heart or the stomach are of secondary importance. Many patients diagnosed with a 'cardiac neurosis', for example, report to cardiologists believing that they have a heart disease, which generally (unfortunately) results in chronic use of benzodiazepines.

Professor Kaczyński emphasized that a characteristic feature of psychoneuroses was that the patients were unable to pinpoint the cause of their ailments. A similar view was held by Noyes and Kolb, who claimed that "understanding neurosis depends on recognizing the unconscious, neurotic purpose it serves (...) the symptoms are a defensive reaction to an anxiety-generating situation (...); the patient himself is unaware of the relationship between his emotional conflicts and situations which he finds difficult, on the one hand, and his disordered personality, on the other"[13]. Kępiński also observes that "psycho-neurosis or neurosis is a type of disorder of the nervous system that is difficult to define in a manner that would be simultaneously concise and precise" [14].
Kaczyński found in his study of patients diagnosed with 'chronic neurosis' that the most common cause of the disorder was a situation of conflict or frustration that was concealed from the patient's conscious awareness. He pointed out that psychological assistance could be necessary (including projective tests) in such cases. A failure to discover the cause of the disease translates into a lack of therapeutic effect of recommended medication. When a patient tries to get help from one doctor after another to no avail, he/she may react with a two-stage 'resignation response' described by Kaczyński [15]. In the first stage (the 'renunciatory resignation response'), the patient, convinced that his/her illness is incurable, withdraws from active life. Recognition of this stage is an indication for hospitalization, because it may, at any moment, transition into the second stage of 'suicidal resignation response'. The patient's decision to end his/her life is the result of a 'cold calculation', and the execution of the decision is carefully planned. Patients with the resignation response characteristically leave a short farewell letter asking for forgiveness.

For decades, and especially since the second half of the eighteenth century, researchers of neuroses representing various schools of thought have been creating multifarious classification systems that have not made it easier for practitioners to deal with those diseases. In the early years of the twentieth century, a division of neurosis into three clinical groups emerged. The first group consisted of syndromes presenting with the clinical picture of 'hysteria', a condition which had been known since 1700 BC. In the Polish literature, a good description of hysteria can be found in Jakubik's 1979 monograph [16]. The second group consisted of disorders, first diagnosed by Beard in 1880 as 'neurasthenia', which included hypersthenic and hyposthenic syndromes. In 1903, Janet introduced the term 'psychasthenia', indicating the typical characteristics of this form of neurosis, among others: shyness, lack of confidence, and proneness to obsessional thoughts. The division of neuroses into these three forms, referred to in the literature as the 'classical division', has been accepted not only by Kaczyński but also by many other authors, among others, Korzeniowski [17]. The Russian psychiatrist Fiedorov recommended that research on neurosis should be based on the "three classic forms of neurosis" because the introduction of "new definitions and divisions only compounds the already complex problem of these disorders" [18].

The most eminent Polish psychiatrist, the author of the Psychophysiological Theory, Mazurkiewicz, described psychoneurosis as 'intra-level dissolution'. He wrote: "we are dealing here with the borderline between logical and prelogical thinking, and, therefore, with the weakest degree of dissolution - limited to one level of mental activity - which 
we refer to at the Clinic as a psychoneurotic syndrome" [19].

The research carried out currently at the Lublin Clinic, which expands on Mazurkiewicz's scientific thought, is an attempt to find points of commonality between the clinical picture of neurotic disorders and the concept of intra-level dissolution. Preliminary results indicate that the three "classic" forms of neurotic disorders correspond to dissolution that runs along the three developmental pathways listed by Mazurkiewicz: epicritic, affective and kinaesthetic.
Przegląd, zarówno czasopism jak i podręczników, opublikowanych w ostatnim dziesięcioleciu - poświęconych zaburzeniom psychicznym - pozwala na stwierdzenie, że wyodrębnione w 1776 roku przez W. Cullena nerwice, uważane za chorobę najpierw XIX a następnie XX wieku, nie wzbudzają obecnie większego zainteresowania klinicystów. Można tu wskazać chociażby na podręcznik H.J. Kaplana i wsp.[1], w którym informacja o nerwicach ogranicza się praktycznie do wymienionego w skorowidzu hasła: -„nerwica roszczeniowa”. Podręcznik oparty był na klasyfikacji DSM-IV.

Rzetelnej wiedzy na temat kliniki nerwic dostarcza lektura, wydanej przez PZWL w 1988 roku, monografii J. Aleksandrowicza „Nerwice, psychopatologia i psychoterapia" [2]. Autor stwierdza, że nerwice: „epidemiologicznie rzecz biorąc, stanowią pierwszoplanowy problem współczesnej medycyny". Chociaż od ukazania się tej pozycji minęło niemal 30 lat, to stwierdzenie autora: „większość lekarzy niewiele wie o tych schorzeniach i czuje się wobec nich bezradna (stąd pacjenci szukają pomocy u różnych specjalistów i „uzdrowicieli”)” - jest ciągle aktualne.

Potwierdzeniem „zagubienia się" w diagnozowaniu zaburzeń nerwicowych, są rozpoznania spotykane w archiwalnej dokumentacji lekarskiej, stawiane nie tylko np. przez lekarzy rodzinnych, ale także specjalistów psychiatrów. Można spotkać określenia nerwic, m.in.: - „lękowa, wegetatywna, sytuacyjna, hipochondryczna, serca, roszczeniowa, urazowa” itd. Na ostatnie z określeń zwracał, już dawno, uwagę T. Bilikiewicz, jako: - „wprowadzające w błąd", gdyż przyczyną może być, nie tyle czynnik psychogenny ile zmiana organiczna mózgu [3].

Przed ponad 40 laty Z. Falicki proponował, aby u tzw. " pierwszorazowych” pacjentów, zgłaszających skargi typu nerwicowego, stawiać - dopóki nie ujawni się czynnika etiologicznego - wstępną diagnozę „zespołu nerwicowego” [4]. Można tu przytoczyć opis przypadku podany przez M. Basquina - początkowo postawione rozpoznanie nerwicy, zmieniono po pewnym czasie na równie błędną diagnozę schizofrenii, by w końcu rozpoznać chorobę Wilsona [5].

M.Siwak-Kobayashi stwierdza, że zaburzenia nerwicowe: - „, są najczęściej spotykanymi spośród zaburzeń psychicznych w praktyce ogólnej” oraz, że : - „często nasuwają wiele wątpliwości i trudności natury diagnostycznej i terapeutycznej". Zwraca uwagę, na konieczność odróżniania schorzeń uwarunkowanych np. podłożem somatycznym, uzależnieniem czy poronnym obrazem psychozy endogennej [6].

Po 10 latach od ukazania się wspomnianej wyżej monografii J. Aleksandrowicza, pojawiła się monografia A. Kokoszki (wznowiona następnie po 6 latach), poświęcona zaburzeniom nerwicowym [7]. Autor, dostosowując się do obowiązującej od 1998 roku Klasyfikacji ICD-10, stwierdził że: - „termin nerwica pojawia się okazjonalnie i w bardzo ogólnym znaczeniu". Odnosząc się do powstałych wówczas kontrowersji, przytoczył słowa dyrektora Działu Zdrowia Psychicznego WHO Normana Sartoriusa: -,,nie podjęto próby przedstawienia definicji tego określenia w ramach klasyfikacji, a jego obecność ma ułatwić praktykę osobom stale jeszcze posługującym się tym terminem". Wydana ostatnio przez PZWL, pod red. M. Jaremy, monografia: „Zaburzenia nerwicowe w praktyce lekarza POZ”, rozwija informacje zarysowane przez kody alfanumeryczne F.40 -F.48 w Klasyfiakcji ICD-10, stwierdzając: - „jakkolwiek nie stawiamy rozpoznania nerwica, przynajmniej nie w dokumentacji medycznej, to akceptujemy termin zaburzenia nerwicowe, na określenie zaburzeń o mniej więcej podobnym obrazie klinicznym i niewykluczone, że prawdopodobnie wspólnej genezie" [8].

Prof. Mieczysław Kaczyński, uczeń a następnie współpracownik J. Mazurkiewicza, kierował lubelską Kliniką Psychiatrii, w latach 1950- 1971. Głównymi zainteresowaniami naukowymi Profesora były, okres inicjalny i zmiany charakterologiczne schizofrenii. Przedmiotem analiz klinicznym były także m.in. stany emocjonalne osób w okresie inwolucji (opis tzw. „postaw inwolucyjnych”), jak też zmiany psychiczne w przebiegu przewlekłych zaburzeń nerwicowych [9].

Prof. M. Kaczyński podkreślał, że zgłaszane przez pacjenta skargi, które ogólnie można określić jako "nerwicowe”, muszą być poddane wnikliwej analizie klinicznej, która umożliwi zaklasyfikowanie ich do jednej z trzech grup diagnostycznych. Pierwszą stanowią tak zwane , często występujące - „reakcje nerwicowe”, tj. krótkotrwałe dysfunkcje stanu psychicznego, związane z wskazywanym przez pacjenta urazem psychicznym. W obrazie klinicznym, ujawniają się cechy charakterystyczne, dla opisanych przez K. Jaspersa, zaburzeń reaktywnych z symptomatologią - w tych przypadkach bez cech 
psychotycznych - z różnie wyrażonymi, zależnie od cech osobowości, objawami wegetatywnymi. Pomoc psychiatry i psychologa przynosi dobre efekty. Objawy reakcji ustępują bez następstw. Drugą grupę diagnostyczną stanowią tzw. „zespoły rzekomonerwicowe”, których symptomatologia przypomina nerwicowe zaburzenia psychogenne, ale przyczyną są albo: - schorzenia somatyczne, zarówno dopiero rozwijające się (np.: „stadium neurasteniczne” guza mózgu) jak też przewlekłe (np. w przebiegu nadciśnienia tętniczego lub dysfunkcji tarczycy), albo: - rozpoczynające się lub przewlekłe (o przebiegu poronnym) choroby psychiczne. W takich przypadkach - najtrudniejszych diagnostycznie - konieczne są, wielokrotne, w krótkich odstępach czasu, badania kontrolne oceniające strukturę i dynamikę schorzenia.

Zespoły nerwicowe mogą być preludium rozwijającej się podstępnie schizofrenii. Badania Kliniki lubelskiej, pozwoliły na wykazanie cech różnicujących, psychogennie uwarunkowane nerwice, z podobnymi, ale jednak innymi w zakresie struktury i dynamiki zespołami rzekomonerwicowymi wczesnej schizofrenii [10]. Na odrębność obrazu klinicznego zwracali wcześniej uwage M. Kaczyński [11] i M. Masiak [12].

Trzecią grupę zaburzeń z symptomatologią nerwicową stanowią „nerwice prawdziwe”, przez niektórych autorów - dla podkreślenia podłoża psychogennego - nazywane „psychonerwicami”. Rozpoznanie tego schorzenia uwarunkowane jest wykluczeniem wymienionych wyżej „reakcji nerwicowych” i „zespołu rzekomonerwicowego”. Przytaczane na wstępie rozpoznania, jak np. „nerwica sytuacyjna”, „nerwica wegetatywna” czy „nerwica żołądka” są błędne, gdyż każda nerwica jest „sytuacyjną” i „wegetatywną". Stawianie rozpoznań z kręgu tzw. „nerwic narządowych” także jest niewłaściwe. Nerwica dotyczy stanu psychicznego, a zgłaszane przez pacjentów skargi na dolegliwości ze strony serca czy żołądka mają znaczenie drugorzędne. Wielu pacjentów z rozpoznaniem np., „nerwicy serca”, zgłasza się do kardiologów w przekonaniu o chorobie serca, co skutkuje na ogół (niestety) przewlekłym przyjmowaniem benzodiazepin.

Cechą charakterystyczną psychonerwic - co podkreślał prof. M. Kaczyński - jest to, że pacjenci nie potrafią wskazać przyczyny dolegliwości. Podobne spojrzenie prezentowali A.P. Noyes i L.C. Kolb pisząc: - „zrozumienie nerwicy zależy od rozpoznania nieświadomego, nerwicowego celu, jakiemu ona służy... objawy są reakcją obronną na sytuację lękotwórczą... sam pacjent nie zdaje sobie sprawy z zależności między jego konfliktami emocjonalnymi i trudnymi dlań sytuacjami a zaburzeniami jego osobowości" [13]. A. Kępiński również wskazywał, że: - „psychonerwice lub nerwice to trudny do zwięzłego a zarazem precyzyjnego zdefiniowania rodzaj zaburzeń układu nerwowego" [14].
Prof. M. Kaczyński, badając pacjentów z rozpoznaniem „przewlekłej nerwicy”, stwierdził, że najczęściej przyczyną schorzenia były nieuświadamiane sobie przez pacjentów sytuacje konfliktowe lub frustracyjne. Zwracał uwagę, że konieczną bywa pomoc psychologa (m.in. testy projekcyjne). Brak ujawnienia przyczyny, przekłada się na brak efektu terapeutycznego po zalecanych lekach. Gdy nie pomagają wizyty u kolejnych lekarzy, dochodzi do opisanej przez Profesora dwuetapowej „reakcji rezygnacyjnej” [15]. W pierwszym etapie („reakcja rezygnacyjna wyrzeczeniowa”) - pacjent, przekonany o nieuleczalności swojej choroby, wycofuje się z aktywnego życia. Rozpoznanie tego etapu jest wskazaniem do hospitalizacji, gdyż w każdej chwili może rozwinąć się etap drugi - „reakcja rezygnacyjna samobójcza”. Decyzja o zakończeniu życia jest wynikiem „zimnej kalkulacji", a realizacja decyzji jest dokładnie zaplanowana. Cechą charakterystyczną, jest pozostawienie krótkiego listu pożegnalnego z prośbą o wybaczenie.

Przez dziesiątki lat, a szczególnie od drugiej polowy osiemnastego wieku, badacze zajmujący się nerwicami tworzyli różne systemy klasyfikacyjne, które ze względu na mnogość szkół, w których powstawały, nie ułatwiały pracy lekarzom praktykom. W pierwszych latach dwudziestego wieku zarysował się podział nerwic na trzy grupy kliniczne. Pierwszą stanowiły zespoły składające się na obraz, znanej już od 1700 roku p.n.e., „histerii”. W polskim piśmiennictwie dobrze prezentuje to schorzenie, wydana w 1979 roku, monografia A. Jakubika [16]. Drugą grupę stanowiły zaburzenia znane od 1880 roku, które G.M. Beard nazwał „neurastenią”, obejmujące zespoły hipersteniczne i hiposteniczne. W 1903 roku P. Janet wprowadził termin „psychastenia” wskazując na typowe dla tej postaci m.in.: - nieśmiałość, niepewność, skłonność do natręctw. Podział nerwic na wymienione trzy postacie, nazywany $\mathrm{w}$ piśmiennictwie „podziałem klasycznym”, akceptowany był nie tylko przez M. Kaczyńskiego ale przez wielu autorów, m.in. L. Korzeniowskiego [17]. Rosyjski psychiatra W. Fiedorow, zalecał aby w badaniach opierać się „na trzech klasycznych postaciach nerwicy” gdyż wprowadzanie „nowych określeń i podziałów komplikuje i tak złożoną problematykę tych zaburzeń" [18].

Najwybitniejszy polski psychiatra, twórca teorii psychofizjologicznej, J. Mazurkiewicz, określając psychonerwicę jako - "dyssolucję wewnątrzpiętrową", pisał: - "mamy tu do czynienia z pograniczem, pomiędzy myśleniem logicznym a prelogicznym, a więc z najsłabszym stopniem - jeszcze wewnątrzpiętrowej - głębokości dyssolucji aktywności psychicznej, stopniem który w klinice nazywamy zespołem psychonerwicowym" [19].

Prowadzone obecnie w Klinice lubelskiej badania, kontynuujące rozwój myśli naukowej J. Mazurkiewicza, stanowią próbę powiązania obrazu 
klinicznego zaburzeń nerwicowych z koncepcją dysolucji wewnątrzpiętrowej. Wstępne wyniki wskazują, że trzy „klasyczne” postacie zaburzeń nerwicowych, odpowiadają dyssolucji, przebiegającej po trzech, wymienionych przez J. Mazurkiewicza szlakach rozwojowych: epikrytycznym, afektywnym i kinestetycznym.

\section{Conflict of interest}

The author has declared no conflict of interest.

\section{References:}

1. Kaplan H.J., Sadock B.J., Sadock V.A. Psychiatria kliniczna. Wrocław Sidorowicz S.K. wyd. Urban \& Partner, 2004.

2. Aleksandrowicz J. Nerwice: psychopatologia i psychoterapia. Warszawa, wyd. PZWL, 1988.

3. Bilikiewicz T. Psychiatria kliniczna. Warszawa, wyd. PZWL, 1966.

4. Falicki Z. Psychiatria społeczna. Warszawa, wyd. PZWL, 1975.

5. Basquin M. Hysterie, schizophrenie, maladie de Wilson. Revue de neuropsychiatrie infantile. 1975, 23:195-200.

6. Siwak - Kobayashi M. Zaburzenia nerwicowe. W: Wciórka J. red., Psychiatria

7. Praktyczna dla Lekarza Rodzinnego. Warszawa, wyd. IPiN, 1992 , s.138-160.

8. Kokoszka A. Zaburzenia nerwicowe. Postępowanie w praktyce ogólnolekarskiej. Kraków, Medycyna Praktyczna, 1998.

9. Jarema M. red., Zaburzenia nerwicowe w praktyce lekarza POZ Warszawa, wyd. PZWL, 2018, s.11-12.

10. Perzyński J. Profesor Mieczysław Kaczyński 1906-1985. Postępy Psychiatr Neurol. 1992, tom I, Nr 3, s. 233-237.

11. Perzyński J. Struktura i dynamika zespołów nerwicowych inicjujących proces schizofreniczny. Praca doktorska. Akademia Medyczna. Lublin, 1977.

12. Kaczyński M. Symptomatologia wczesnej schizofrenii, Neurol. Neurochir. Psychiatr. Pol. 1957;4:505-511.

13. Masiak M. Z badań nad przewlekłą prostą schizofrenią. Praca doktorska. Akademia Medyczna. Lublin, 1969.

14. Noyes A.R., Kolb L.C. Nowoczesna psychiatria kliniczna. Warszawa, wyd. PZWL, 1969.

15. Kępiński A. Psychopatologia nerwic. Warszawa, wyd. PZWL, 1972

16. Kaczyński M. Reakcja rezygnacyjna w przebiegu nerwic. Neurol. Neurochir. Psychiatr. Pol. 1957; 6: 823.

17. Jakubik A. Histeria. Warszawa, wyd. PZWL, 1979.

18. Korzeniowski L. Zarys psychiatrii. Warszawa, wyd. PZWL, 1967.

19. Fiedorow W.K. O formach newrozow. Żurnał Newropat.i Psychiat. S.S. Korsakowa. Moskwa. 1960.T.LX.wyp10.1306-1310.

20. Mazurkiewicz J. Wstęp do psychofizjologii normalnej. T.II.

21. Dyssolucja aktywności korowo-psychicznej. Warszawa, wyd. PZWL, 1958

22. Kaplan H.J. Sadock B.J. Sadock V.A. Psychiatria kliniczna. Wrocław, Sidorowicz S.K. (Ed.) Wydawnictwo Urban \& Partner, 2nd Polish Edition, 2004
23. Aleksandrowicz J. Nerwice, psychopatologia, psychoterapia Warszawa, wyd. PZWL, 1988.

24. Bilikiewicz T. Psychiatria kliniczna. wyd. PZWL. 3rd Edition 1966, 260-263.

25. Falicki Z. Psychiatria społeczna. Warszawa, wyd. PZWL, 1975.

26. Basquin M. Hysterie, schizophrenie, maladie de Wilson. Revue de neuropsychiatrie infantile.1975. 23(3-4).195-200.

27. Siwak-Kobayashi M. Zaburzenia nerwicowe. W: Wciórka J. (Ed.), Psychiatria

28. Praktyczna dla Lekarza Rodzinnego. Warszawa, IPiN, 1992 (138160).

29. Kokoszka A. Zaburzenia nerwicowe. Postępowanie w praktyce ogólnolekarskiej. Kraków, Medycyna Praktyczna, 1998 1st Edition, 18-19.

30. Jarema M. (Ed.), Zaburzenia nerwicowe w praktyce lekarza POZ. wyd. PZWL. Warszawa, 2018: 11-12.

31. Perzyński J. Profesor Mieczysław Kaczyński 1906-1985. Postępy Psychiatr Neurol. 1992, I. 233-237.

32. Perzyński J. Struktura i dynamika zespołów nerwicowych inicjujących proces schizofreniczny. Doctoral dissertation. Akademia Medyczna. Lublin, 1977.

33. Kaczyński M. Symptomatologia wczesnej schizofrenii, Neurol. Neorochir. Psychiatr. Pol. 1957, 4, 505-511.

34. Masiak M. Z badań nad przewlekłą prostą schizofrenią. Doctoral dissertation. Akademia Medyczna. Lublin, 1969.

35. Noyes A.R. \& Kolb L.C. Nowoczesna psychiatria kliniczna. Warszawa, wyd. PZWL, 1969.

36. Kępiński A. Psychopatologia nerwic. Warszawa, wyd. PZWL, 1972.

37. Kaczyński M. Reakcja rezygnacyjna w przebiegu nerwic. Neurol. neurochir. psychiatr. pol. 1957, 6, 823.

38. Jakubik A. Histeria. Warszawa wyd. PZWL, 1979.

39. Korzeniowski L. Zarys psychiatrii. Warszawa, wyd. PZWL, 1967.

40. Fiedorow W.K. O formach newrozow. ZhNevrol Psikhiatr. Im. S.S. Korsakowa. Moskwa. 1960.T.LX. Issue 10.1306-1310.

41. Mazurkiewicz J. Wstęp do psychofizjologii normalnej. Vol. 2 Dyssolucja aktywności korowo-psychicznej. Warszawa, wyd. PZWL, 1958.

\section{Correspondence address:}

\author{
Aneta Perzyńska - Starkiewicz \\ II Klinika Psychiatrii i Rehabilitacji Psychiatrycznej \\ Uniwersytet Medyczny w Lublinie \\ 20-439 Lublin, Głuska 1
}

Otrzymano: 17.02.2018

Zrecenzowano: 21.03.2018, 04.09.2018

Przyjęto do druku: 20.09.2018 